\title{
新しい形態のゴム加工方法
}

\section{金子秀 男}

\section{1. 形態の重要性}

ゴム加工用として供給される原料ポリマーの形態は従 来, 固形状のシート，ブロックあるいはペレットと液状 のラテックスに大別できる，加工技術むしたがって原料 の荷姿, 形態によってそれぞれの加工機械, 設備はもち ろん配合や加工方法や加硫実技む適合した内容で進歩し 今日に至った.

今仮に原料ポリマー形態に技術革新が起こって, 液状 なり粉末状のポリマーが市場に登場するとしよ5. 新形 態によって加工方法が合理化され，物性面でも同等だと メーカー側の宣伝が利き，実際にそうであっても，はた してユーザー側が早速これに切り換えるだろらか?この 解答は過去の歴史的事実が雄弁に物語るだろ5.

1922年のU. S. 特許 1, 423, 525に有名な Hopkinson 法 なる粉末ゴム製造方法があり，更にそのころこれを圧搾 した L. Sゴム (Sprayed Latex Rubber) が市場に出たこ とは古いゴム屋さんならご存知のはずである，また，我 が国でも電気試験所で湊谷氏などがゴムの粉末化とその 利用に関する研究と題する報文の発表が当協会誌上にあ る. $(1$ 報 : 7, $272(1934): 2$ 報：9，53(1936)：3 報：9，67(1936)) 更に丸薬状ゴムと題する粉末ゴムの 加工技術についての訳文がー一かくしてコムは自動的に 輸送され，ひょ5量されん—と今の粉末ゴムと同じメ リットを誇った（日ゴム協誌：15，438 (1942)).それに るかかからず消減したその理由を考えると，

1）長年の加工技術の保守性が強かっったと.

2)メリットよりデメリットが多かった（L.Sラパー の練りにくさはいまだに私として忘れ得ない)こ 之.

3）巨大設備費の偵却しない内は新機械の設備など考 えられぬこと。

*技術士（宁250小田原市城山3-23-15）
4) オール天然ゴムのため, 粉末化しても粘着固体化 してしまうこと.

など挙げられる．液状ゴムにしても英国の RUBBON や 米国のD.P.Rubberなど1930年代の登場だが，いまだに 低迷しているのが実状である.

初めから失敗談的情報ばかり不吉なことを申し上げた が，要するにポリマー屋さんがどんな形態のものを供給 されても，受入側のゴム加工側に，充分な受入れ体制な り，技術的準備がなければだめだとあえて直言したい。 いまや天然ゴムと合成ゴムとを問わず世界中のメーカー は粉末化や液状化の形態改善の研究をやっている．試作 的には成功し，商品化のチャンス待ちであるのが現状と 言って良からう．欧州ゴム工場では既に各種粉末ゴムの 実際加工が初まり，薬品屋さんむ機械屋さんも急けずに それ用の研究がひそかに始まっているよし、我が国でも 特殊のゴム板製品，例えば新幹線のバラストマットなど 粉末ゴムの亜流加工も既に実施されている，液状ポリマ 一の商品化もご案内のと拈りである.

\section{2. 加工技術展望}

粉末ポリマーの加工はプラスチック界では常識であ る.しかしゴムはプラスチックと違った次の 3 要素が不 可久であることはご案内のとおりである.

(1) 素練り効果（ラジカル発生の利用）

(2) 加硫効果 (一次架橋の利用)

(3) 補強剂効果 (二次架橋の利用)

近ごろ素練り不要とか非加硫性ゴムとかが登場してい るが，石頭の筆者は正規な加工技術とは思っていない. 液状ないし粉末状ゴムの加工方法でもこの 3 要素をどの ようにして最高レベルに発揮するかが闍題である。単に 外観的形態から見てひ上5量, 混合, 成形が従来の方法 に比較して，はるかに単純化，連続化されるかの早のみ こみされる方が多い，しかし実際にゴム工場の現場で苦 
労をした技術者諸君なら，一定の可塑度，分散度，加硫 度がはたして得られるだろらかと疑問を持つに違いな い. ゴムの加工技術は一見旧式でやほ臭い(プラスチッ ク加工方法と比べた場合）よ5だが，実は100年以上の 経験苦心の結果が最良と思われる今日の加工技術に収ま ったもので，ばかにしたものではない．前の3要素を完 全に満たすよ5な理想的な新しい形態ゴムが仮に市場化 しても，多種類のゴム用途, 複雑なゴム加工技術を駆使 できるまでには，かなりの年月を必要とすることを覚梧 すべきであろ 5.

1971年 Du Pont社の有名な「末来のゴム加工技術」ア ンケート集の結果を見ても (Delphi Probe)，

粉末ゴムの場合 : 本命と見られる押出コム製品でも20 \%に達するのが1980年.

液状ゴムの場合：1985年以後に商品化できるだろう． と残念ながら消極的ご宜託である。

これからら話する順序もこれに従って粉末ゴム，液状 ゴムと進むが，現在騒がれている新形合成ゴム粉末の外 に，昔から我々ゴム屋にひそかに愛用されている粉末再 生ゴム, 粉末加硫ゴム (バフ粉) などの加工方法にも触 れたい.

䉼りするまでもないが，粉末ゴムや液状ゴムの加工 技術も現在の段階ではポリマーメーカーなり，機械メ一 カーのカタログ的文献のため，公平を期しにくい点があ るが知れぬが，ご蜸察されたい。

\section{3. 粉末ゴムの加工技術}

粉末ポリマー, 配合剂, 配合特性, 加工機械, 加工方 法，加硫その他など，特に従来ゴム加工方法との相違点 を中心に打話を進める。

\section{1 粉末ポリマーの現状}

文献などで粉末化可能のポリマーとしては，NBR，N R, CR, SBR, BR, EPDM など挙げられているが実際 の商品化は意外に少ない。試作のX番号のものは除く。 (表 1 )

したがって現在の粉末ゴム加工に関する文献はほとん どNBR中心で,他のポリマーはこれに準趐してやるべき だといった程度に止まる。

なせ NBR だけが粉末ゴムの開拓者として特に進出し たかを考えることは粉末ゴムの加工と将来性を考える上 で重要な意味を持つので説明したい，ご案内のように20 年ぐらい昔加ら NBR は PVCとの相溶性, 部分架橋性加 らブレンドされ実用に供された．PVC の粉末状に対し NBR の粉末化も古く加実施され，加工方法\& PVCの
表 1 現在确品化されている䊏末ゴム

\begin{tabular}{cl}
\hline 型 & \multicolumn{1}{c}{ 商 品 名 } \\
\hline NBR & Hycar 1431 P-65*1 \\
& " 1432 P-80 \\
& " 1452 P-50 \\
& Krynac 34.50 Powder*2 \\
NR & NR. Mealorub Dynat. \\
& Heveacrumb よどペレット化の発表あり \\
EPDM & Epsyn 5508, 5509,*3 \\
\hline
\end{tabular}

注:*1 Pは粉末，65はムーニー值を示す。

*2 34はアクリロニトリル含有量, 50はムーニー值 を示す.

*a 手でもむだけで容易に粉末化 (friable) できると いわれる。

連続的粉末処理のやり方に沿うべくくふら改良の研究が 行われ，これが独立した NBR だけの粉末コム加工方法 にまで発展したのである。そしてその優れた加工性が他 のポリマーゴムに刺激を与え，今日の粉末ゴム待望時代 となった.

粉末化は原理的に次の3方法あるいは併用で技術的に は難しくはない

1) エマルジョン又はラテックスのスプレー式乾燥 (粉末ミルク方法)

2）エマルジョン又は溶液の楥やかな凝固沈殿によ 万.

3）機械的冷凍化ゴムの破砕粉末化による.

問題は粉末化されたゴムの再集合を防止する最小限の 打粉 (粘着防止) と，粉末ゴムとして混合，押出処理中 にその打粉でじゃむれぬ（粘着促進）ための分散凩の 相反する二つの性質をいかに粉末ゴム中に組み入れる (built in) かにある.そしてこれがポリマーの化学成分 とか結晶性などによって相違する。この方面は専門の執 筆者に扣䛊りし，加工の立場から次の 2 点だけ付記す る.

3.1.1 粉末度 Wわ仂る自由流動性 (free flowing powder）としての立場から，現在 NBR の場合次の粒子 径と均一性が要求されている（図 1，表 2)

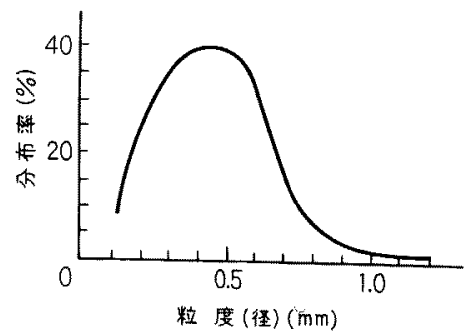

図 1 粉末ゴムの粒度分布 (仏 Goodyear 社データ) 
表 2 粉末コムのふるい試験 (Polymer Corp データ)

\begin{tabular}{ccc}
\hline Krynac 34.50* & ふるい $(x ッ シ ュ) ~$ & (残留\%) \\
\hline 1. ふるい残留 & 25 & 0 (全通) \\
" & 50 & 77.8 \\
" & 100 & 94.3 \\
& 200 & 98.3 \\
2. ムーニー值 & \multicolumn{2}{c}{50} \\
3. (ML-4 at $\left.100^{\circ} \mathrm{C}\right)$ & \multicolumn{2}{c}{$1.8 \%$} \\
\hline
\end{tabular}

3.1 .2 価格 粉末化の加工儥の付加で，従来のベー ル状固形ゴムに比較して $+12.5 \%$ のコストアップは免れ ぬよし，これは加工者にとって最大関心事である。

3.2 粉末コム加エプロセス

現在は固体と粉末ゴムの過渡期として次図のような従 来の heavy duty 形の併用が実用的で，主流は

1) 粉末の自動ひょ5量, 空気輸送, 粒体眝葴

2) 予備混合 (Henschel形)

3）短時間強力混合（開放又は密閉形混合ロール）

4) 射出成形加硫

5）押出機よりプレス加硫又はシーティングの生作り の図 2 の直線方式である。

しかし粉末ゴムの最大特長であるバッ千方式の排徐の 連続加工方法としては押出混合機（ミキストルーダー） 方法なり，粉末コンパウンド方法による図 3 の分散式バ イパス方式を採用すべきである。

以上はあくまで基本プロセスで粉末ゴムのポりマー的 性状，配合剤の種類によってそのまま採用できず，かん じんの加工機も現在では従来の PVC 用の HenscheI ミ キサーやプラスチック用ミキストルーダーを流用してい るにすぎない，つまり将来粉末ゴム用として特別設計さ れた加工機械の登場によってむっとスッキリした能率的 プロセスになるであるら。

粉末ゴムの加工プロセスから見て押出製品特にホッパ 一からの自動供給に始まり強力な混合，押出，成形そし て加硫を連続的に行う射出成形用として理想的な形態ゴ ムであら 5

\section{3 予備混合方法 (Rre-mircing)}

粉末自動ひょ5量方法は今日の常識だから省略して予 備混合方法から始める，適当な粒度分布に調節された粉 末ゴムと従来の粉末ゴム配合剂のいわゆるドライブレン ドを完全に行えばよい，といってへたにかき混ぜれば発 熱のためせっかくの粉末化ゴムが粘着を始め普通の可智 化ゴムの塊に化してドライブレンドの粉同志の平均分散 混合ができなくなる。
粉末ゴム

配合用粉末

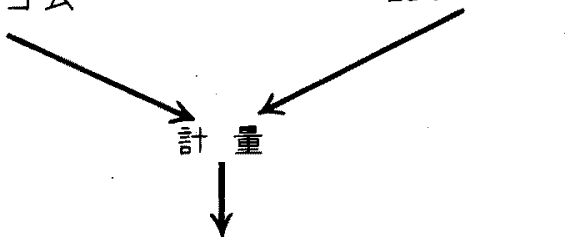

予備混合

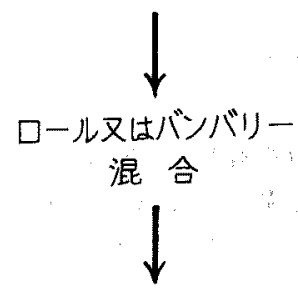

分出し, 生作D<smiles>[3H]C</smiles>

押出, 射出成形。

型物, カレンダーシート

汹 2 過渡期の直線式粉末コム加エライン
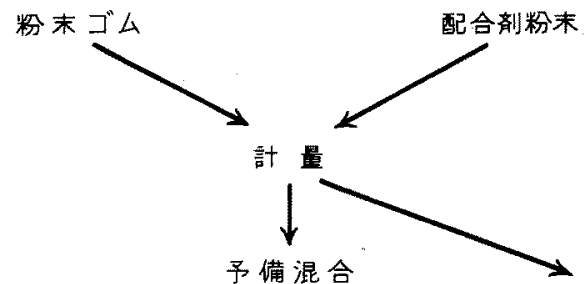

$$
\text { シキストルーダー }
$$

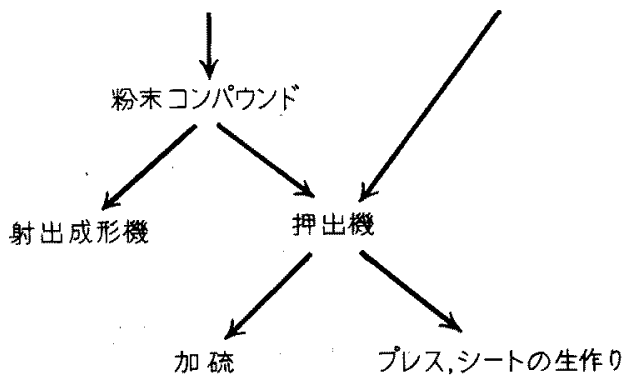

図 3 本式分散式粉末ゴム加エライン

Henschel 形 の 低せん断応力, 高速度回転式混合機か 使われる理由である.PVC関係の技術者には常識だが， ゴム関係の方くのために簡単に説明しよう。

図 4 は Henschel の機能部分たる 3 枚の impellor (5 ず巻きポンプの羽根車に相当する）を示す，毎分数千回 の高速度回転で，異種粉末がぶつかり合いながら集合を 

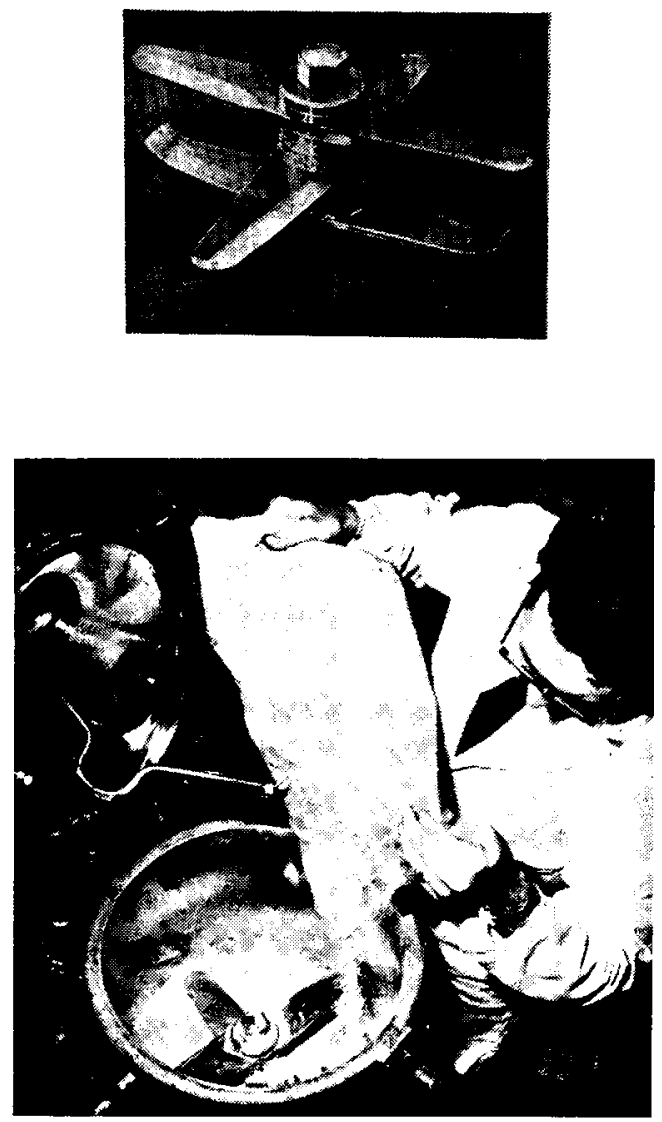

図 4 Henschel 型予備混合機のインペラー(上)と 粉末ゴムを添加するところ(下)

破壊し相互分散を完全にする原理である．PVC 加工の 場合は普通 1 台のバンパリーミキサーに対し 2 台のヘン シェルが付属し, 混合周期を 2 倍以上に高速化し, バン バリーのみ使用時の分散不良をむ解决したが，このメリ ットを粉末ゴムの場合に応用する. しかし実技ともなる とこのヘンシェルの使い方にも多分にノウハウ的な点が ある、例を挙げると, 初めに微粒子, 多量のカーボンブ ラックなど配合剤を加え 2,000 rpm の低速回転で行い， 終わりごろに粉末ゴムを添化し3,500 rpm の高速短時間 で処理する例の逆練り Up-Side-down方式がドライブレ ンドには都合が良い.

次に大事な点は，粉末ゴムの表面をカバーしているダ スティング㶡をできるだけ除去し，その代わりにカーボ ンブラックなどと一種の置換作用をこの予備混合で行わ
ねばならぬ，その目的のための特殊薬品として分離隹

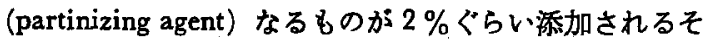
5である.しかしそれがステアリン酸垔鉛と知っていさ さかガッカリだが，このへんにカーボンブラックなどの ラジカル補强効果付与の難しい粉末ないし液状ゴムの混 合技術のミソがあるらしいので，今後の文献でもこの辺 に特に注目願いたい。

\section{4 バンバリー本綵方法 (マスターミキシング)}

せっかくの粉末ゴムをここで元のもくあみの固形ゴム にもどすようで不平があるかも知れぬが, 現在の粉末ゴ 厶加工方法としては前記図 2 のよに残念ながら過沒期 の便法として重要かつ婜明な加工方法である.

粉末ドライブレンドと従来の固形ゴムのバンバリー練 りの場合を表 3 で比較する．同じバンバリー混合でも粉 末ドライブレンドゴムの場合は 2 分足らずで固体ジムの 場合の 5 分に対し半分以下に短縮され，分散度も改良さ れる.

次にオープンロール்方法だが, 同様に粉末ドライブレ ンド方法の特長により，表 4 のよらに1/5以下の混練時間 の短縮化が可能で，練り上がりの物性む優れている（表 5 ).

\section{5 ミクストルーダー (Mix-truder) 加工方法}

粉末ゴムの本格的加工方法で，投入口（ホッパー）上 り連続的に添加し，スクリュー回転みぞに沿って練ら れ, 分散され, 所定の形状に連続的に吐入される. 従来 の固形ゴムの場合, バンバリー湜合機のダンプ後の処理 に実施されていることは諸君の知るところであろう。

しかしドライブレンドの粉末ゴムの配合物の場合は原 則としてバンバリーは省略されるので，ミクストルーダ 一のみで行5場合はバンバリーの代用をも兼ねる必要が ある. したがってこの目的のためのミクストルーダーと しては, 設計上の理論 L/D として 30/ 1 とい5極度に長 い押出機を必要とする，実際問題として製作的にも，操

表 3 No. 3 形バンバリー混練サイクル (ポリサー社データ)

\begin{tabular}{|c|c|}
\hline 粉末ドライブレンド使用 & $(\min )$ \\
\hline (ドライブレンド添加回転 & 0 \\
\hline 混練 No. 3 (sweep down) & $11 / 4$ \\
\hline |ダンプ & $13 / 4$ \\
\hline 固体ゴム使用 & (min) \\
\hline $\int+\exists ゙ ム$ 添加 (素練) & 0 \\
\hline ＋配合剂添加（混練） & 2 \\
\hline （+カーボン（残量） & $21 / 2$ \\
\hline ダンプ & 5 \\
\hline
\end{tabular}


表 4 オープンロールによる比較

（ポリサー社データ）

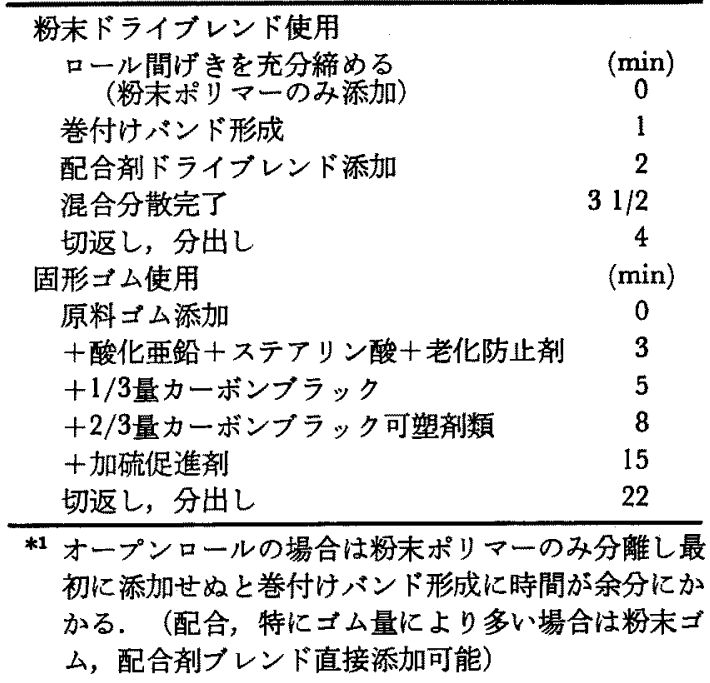

表 5 オープンロール混練の物性比較*1

\begin{tabular}{|c|c|c|}
\hline 粉末ドライブレンド & & $\begin{array}{l}\text { 従来固形 } \\
\text { 百么方法 }\end{array}$ \\
\hline \multicolumn{3}{|l|}{ 末加硫物性 : } \\
\hline \multicolumn{3}{|c|}{ レオメーター $\left(@ 166^{\circ} \mathrm{C}\right)$} \\
\hline 初期加硫速度 (min) & 2.5 & 2.8 \\
\hline 最適加硫時間 (min) & 6.3 & 6.3 \\
\hline \multicolumn{3}{|l|}{ 加硫物性： } \\
\hline $100 \% モ シ ゙ ュ ラ ス ~\left(\mathrm{~kg} / \mathrm{cm}^{2}\right)$ & 14 & 16 \\
\hline 引張強さ $\left(\mathrm{kg} / \mathrm{cm}^{2}\right)$ & 95 & 94 \\
\hline 伸 び (\%) & 700 & 540 \\
\hline 硬さ（ショアーA） & 69 & 67 \\
\hline
\end{tabular}

*1 配合表 :

\begin{tabular}{|c|c|c|}
\hline Krynac 粉末ゴム & 100.0 & Krynac 普通ゴム \\
\hline ZMBI (老化防止剤) & 1.5 & 1.5 \\
\hline $\operatorname{Aminox}(")$ & 1.5 & 1.5 \\
\hline 酸化亜鉛 & 5.0 & 5.0 \\
\hline ステアリン酸 & 0.5 & 0.5 \\
\hline FEF ブラック & 35.0 & 35.0 \\
\hline MTブラック & 65.0 & 65.0 \\
\hline パラプレックスG-50 & 10.0 & 10.0 \\
\hline 可塑剂 SC & 10.0 & 10.0 \\
\hline 加硫促進剂 Santocure & 2.5 & \\
\hline " TMTD & 2.0 & \\
\hline Hisil 233 & 2.5 & \\
\hline
\end{tabular}

注意!! 1. 本配合表には硫黄が含まれぬ（4チウラ 厶多量の無硫黄加硫方法

2. 無硫黄加硫のため老化防止剤の添加量多 いことに注意

3. ホワイトカーボンの少量は分離剤的効果 を狚ったか?
作上でも不可能に近く，この打開策が各メーカーによっ て講ぜられている.

現在粉末ゴ用のミクストルダーとして実験用として 使用されている機種を挙げると

1) Werner und Pfleider社 (西独) ZSK-53及び-83

2) Stewart Bolling 社 (米) Mixtrumat

3) Farrel 社 (米) Transfermix の改良形

残念ながら内部の構造機構については未発 表である が，L/D の短縮化の目的で, twin screw 型か multi-pass （数回連続通過方法の方向に進んでいるようである. ス クリューの構造も粉末ゴム用に研究が進み図 5 のよ5な 発表もある. 余り專門的江深入りするので省略するが， 興味のある方は次の文献参考下さい（Widmer など： Rubber Age, 1974, nov. 44)

要するに，いままで抑制してきたねじ応力をこの場 に及び一挙に加え，粉未ゴム本来の素練り，混練效果を 発揮せしめ，ラジカル反応とか補強肪の分散勃果を充分 行らゴム加工技術で重要な練りの場である。 したがって 構造的にも heavy dutyで，過熱防止の冷却装置にも簃重 な自動制御が必要である．流動性粉末ゴムをミクストル ーダー中に送り込むためにはかなりの背圧（バックプレ ッシャー）を受け，容易ならざる作業であることは，押 出機の現場作業の経験のある方なら容易に予想されるだ ろ5.特に L/D が30/1 とい5とてつもなく細長く、ね ビり応力が大きい場合，粘り気のない粉末ゴムブレンド である。この一見不可能に思われることに敢然と取組ま なければならぬのが，粉末ゴム加工技術者と言えよ 5 。

ミクストルーダーは押出機を利用した混合機であり， これを押出機として成形作業に直接使われない，能率的 にも精度の点でも専用押出機とは立ち打ちできない，

特筆すべきは，ミクストルーダーによる粉末ゴムのド ライブレンド混練方法は短時間で練続的作業のため，可 塑度や分散度も一定になりやすく，熱履歴もほとんど無 視でき，かなり強力な加硫促進肪でもスコーチのおそれ 少なく, 加硫の高能率も可能とメーカー側が誇示してい
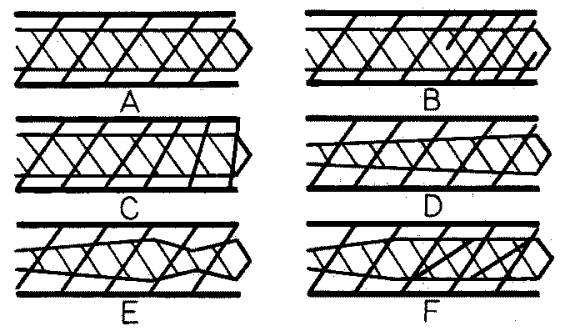

図 5 粉末ゴム用混合押出機のスクリュー構造種類 
る. 一方英国ダンロップ社のホース工場ではミクストル ーダーではなく，普通押出機（ただし $\mathrm{L} / \mathrm{D}=12.5 / 1 ） を$ 使用し, 高速度 intensive mixer でプレドライブレンド した粉末 NBR でりっぱな押出ホース加工に成功したと の報告もある。また連続プレス加硫機として有名な西独 AUMA（米，ROTOCURE 相当）を使用し，粉末ゴム より加硫ゴムシートに成功の情報もある、いずれにせ 上，粉末ゴムの研究が米国であるのに，加工研究がヨー ロッパがより積極的であることに注目すべきである.

\section{6 射出成形加硫方法その他}

現在射出成形加硫ではペレット状コンパウンドの自動 供給による連続加工は常識である。したがって一歩進ん だ粉末ドライブレンドに切り換え得ることはそれ汪ど難 事ではない，特に狙力な射出圧力を利用するスクリュー とラムの併用によるいうゆる reciprocating形押出機内で 粉末ゴムの必要とする補強充てん剤との完全融合も可能 であろ5．現に Desma 社の大型射出成形機905/1形にあ る種の高速度ドライミキサー（西独 Papenmeier 社製か ?）を直結しある種の粉末ゴム配合の射出成形の試験を やっているとの情報に接している.

要するにミクストルーダーのような特殊な融合的混合 押出機を必要としない射出成形法は, 後述の液状ゴムの 埸合と同様粉末ゴムの場合も射出成形加硫方法が加工の 主流となるだろらことは今日の定説である.

その他一般プレス成形加硫やカレンダー分出しシート 加硫にも，押出機を利用する生作り (pre-former)や丁型 口金や横出し方式による幅広, 薄物シートにも粉末ゴム の利用は可能視されていることは前述（図2，3参照）の とおりである。

\section{7 粉末ゴム加工の得失}

粉末ゴム配合物のドライブレンド方法により予備混合 した前記表 5 配合につき, NO. 3 バンバリー方法の本練 りと，二軸式ミクストルーダーによる連続練りによるコ ンパウンドを射出成形加硫した製品物性試験比較を表 6 に示す。

次に重要な加工採算点からの比較表である（第 7 表). No. 3 バンバリーミキサーと前述紹介のW. P 社のZSK53形ミクストルーダー(商品名 CONTIMIX ?) 使用の 本練り成績，能率から見たものである.

結論としてミクストルーダーは機械そのものはバンバ リーよりはるが安いがそれだけ生産量も約 $1 / 3$ 低い。 だしキロあたり生産コストはかなり安く，粉末ゴムの場 合は有利といえよう。

以上はいずれもN B R 系粉末ゴムの加工洗概略に過ぎ
表 6 粉末ゴム配合のバンバリー練りと連続ミクス トルーダー練りの射出成形加硫比較

\begin{tabular}{|c|c|c|c|}
\hline & \multicolumn{2}{|c|}{ 莐バリー } & $\begin{array}{l}\text { 二軸式ミクスト } \\
\text { ルーダー練り }\end{array}$ \\
\hline \multicolumn{2}{|c|}{ 硬さ（ショアーA） } & 67 & 73 \\
\hline $100 \%$ 引張応力 & $\left(\mathrm{kg} / \mathrm{cm}^{2}\right)$ & 14 & 18 \\
\hline $300 \% \quad " \prime$ & $(\%)$ & 60 & 67 \\
\hline 引張強さ & ( $\%$ & 71 & 77 \\
\hline 伸 び (\%) & & 340 & 380 \\
\hline 圧縮セット（\% & & 53 & 50 \\
\hline
\end{tabular}

（注） Lewis ラム式射出成形機サイクル21/2分 @193 ${ }^{\circ} \mathrm{C}$, 結論としてミクストルーダー方法が若干優 れた加硫物性を与えた。

表 7 生産コスト比較

\begin{tabular}{lcc}
\hline & No. 3 バンバリー & \multicolumn{2}{c}{ ZSK-53ミク } \\
ストーダー
\end{tabular}

す，一般論として技術的内容紹介まで到達できなかっ た. しかし粉末ゴム形態による新しい加工技術的方向に なんらかの示唆を与えるものと信ずる. そして現実的に 可能促進するものは, 量的, 用途的にも過半を占める一 般用ゴムの粉末化に期待することが多い.

最後に粉末ゴムの将来性であるが，米グッドリッチ・ ケミカル社の粉末ゴムの特長につきPR広告を借用す る.

(1) 混練時間が $80 \%$ 節約できる.

(2) 動力消費も大いに減少できる.

(3) 混練温度も低温でスコーチの危険が少なくなる.

(4) 能率的自動連続加工, 省力化の可能.

\section{8 粉末ゴムの先駆者としての粒状ゴム加工}

粉末ゴム加工を進行形とすれば，粒状ゴム加工は現在 完了形である，粒子の大きさはチップ状，ペレット状と 粉末ゴムに比較してはるが粗大，不定形ではあるが，加 工技術の本質は大差ない，特に注目すべき柱，原料ゴム に止まらず；加硫ゴムの粒状ないし再生ゴムの粒状を直 接利用して成形加工する新技術が既に新幹線のバラスト マットなどに実施されている，粉末と粒状の差異だが，

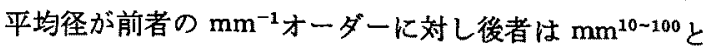


はるかに粗粓でばらつきも大きい，製造方法は原料ゴム の場合は従来の混練後に特殊ペレタイザーなりカッター を利用して容易に得られ，加硫ゴムの場合は再生ゴムの 例のクラッカーロールを使用する。

粒状ゴムの加工は各方面に実施されている．例えば二 連式バンバリー湜練法，射出成形の自動供給など代表的 であり，その特長が理解されつつある。

1） バッチのランニングストックが少量（従来の1/3) ですむ.

2）かき混ぜ冷却によるスコーチの防止，混合ばらつ きの低下.

3）計量, 運般, 眝蔵の簡便.

4) 自動化, 省力化.

要するに粒状ゴムの加工㤋末ゴムほどはでな宜伝を やっていないが，現実的には着々先駆者としての立場に あることを認めるべきであろう。

\section{4. 液状ゴムの加工}

液状ゴムの基礎的加工技術については英国 RAPRAの Dr. Berry の報告（本誌：45. No. 3，266 (1972))をご 覧いただいたものとし，その後の開発進展を中心に説明 をする．最近我が国でも BR，CRなどの液状ゴムが商品 化されているので参考になれば幸である. 卒直に言って 液状ゴムは粘ちょら液状で扱いが不便, 混合特に補強充 てん剂との分散融合も困難, また最大の特長と言われる 延伸架橋理論も実技となる架棌密度特に有効架虂のコン トロールにいまだ研究の余地が残されているが，加工機 械や方法の進歩には目党ましいものがある.

粉末ゴムの場合に準し予備混合, 强力混合, 後期混合 兼貯蔵，射出成形の順序で紹介する. 機械装 圈の説明

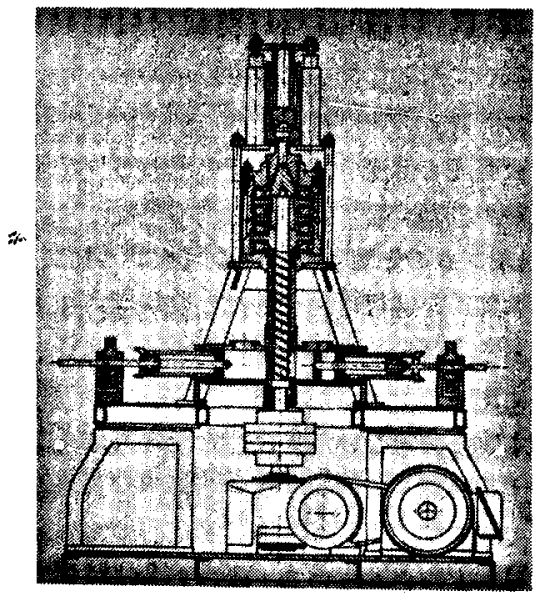

図 6 液状ゴム混合機全容 (RAPRA)

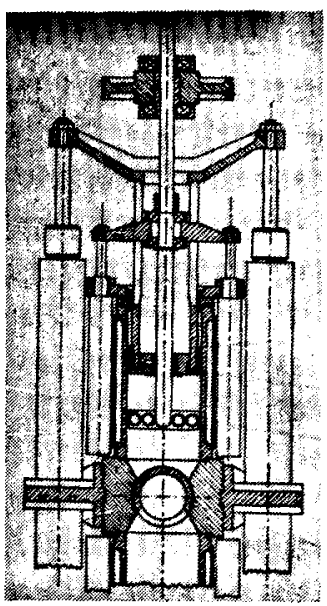

脑 7

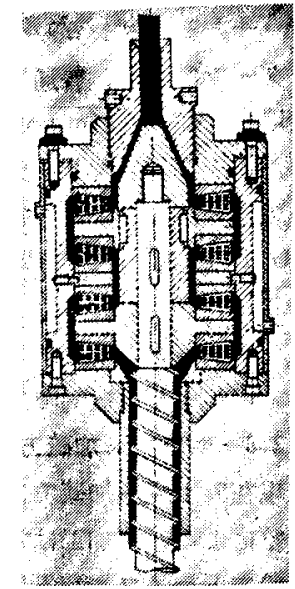

図 8 インテンシブミキサ 一の詳細図 (RAPRA)
(RAPRA)

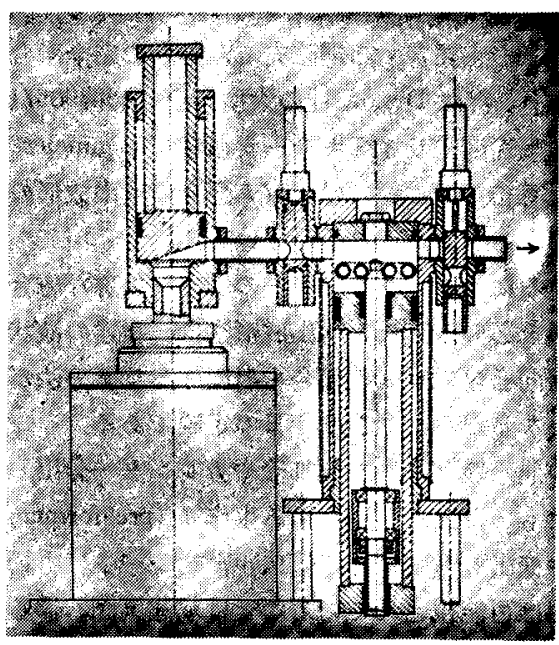

図 9 ポストミキサー(RAPRA)

は，図面や写真中心に進めたいが，余りにも専門的な細 い点や特許関係でぼかされている部分は省略せざるを得 ない. 大体の要領だけ知っていただきたい.

\section{1 ミキサー（ブレ及ひインテンシブ)}

初めに図 6 は RAPRA液状ゴムのミ、キサー全体図であ る. パッキング配合で10馬力モーターを使用毎時 $25 \mathrm{~kg} の$ 能力を有し，連続的にソーセージ状の形で上部より押出 される．下部がホッパー兼プレミキ甘ーになって左右の ラム形二連式押出機からなる.

図 7 はその片方をかかりやすく垂直図形で拉大したも の,ラムで下部円形内に押し出され，図6の垂直スクリ ニーに乗って上方の强力（インテンシブミキサー）に送 り込まれるが，その途中スクリュー作用で予備混合が行 われる. 左右 2 台の往復運動で連続作業可能. 図 9 のイ 
ンテンシブミキサーは液状ゴム混合分散の死命を制する 重要装固で，急所だ时説明すると, 强力高速度回転でス リットを通りながらせん断応力と摩嚓と遠心力をフルに 応用しつつ 4 段階を上部方向に進む. そして最後に中央 部の三角状の吐出スリットを経て上部へ送られる。

\section{2 䝪蔵タンクとポーストミキサー}

強力ミキサーの上部江図10の左側の貯蔵筒で下部に連 結される.これは一種の後期 (ポスト) 混合のための予 備混合室をも兼ねる. 特殊の高速架橋剂は強力ミキサー 中で発熱作用でスコーチのおそれがあるのでこの貯蔵筒 で予備混合した後，図10の右側のポスト混合機内に誘導 し, ラム形押出機で混合分散を完了させる.

ポストミキシングを必要とせ婸合は，貯蔵タンクの ラムを下げた状態で（図面どおりの場合）右側に回り， ポストミキサー中に貯藏される.そしてラム庄により次 の加工機に送り込まれる。

\section{3 射出成形加硫方法}

液状ゴムの成形加工の特長は, 従来の固形ゴムの高粘 度に対して流動性のため，成形圧力が低く，金型も銤物 製でも耐える. 特に射出成形の場合でも，

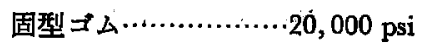

$$
\begin{aligned}
& \text { 液状ゴム……………...... } 600 \text { psi }
\end{aligned}
$$

\section{と射出圧力も約 $1 / 40$ でまと合らと言われる。}

図11は波状ゴム射出成形方法によるタイヤキャッピン グ (再生タイヤ) で中央部から上，下のモールドへ送り 込む方法を示す. したがって軽便形射出成形機でも充分 連続使用に耐え，一時に図12に示すよ5に6セットの交

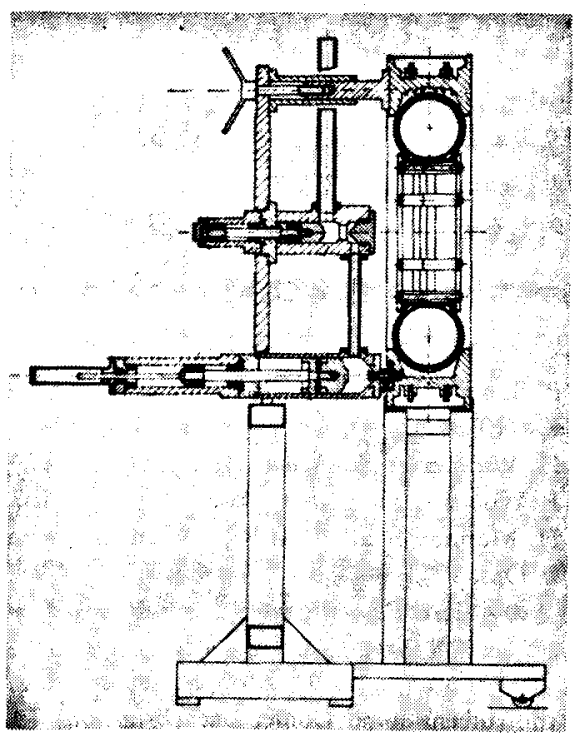

図10 液状ゴム用のタイヤ射出成形モールド
互運動も可能である．図13はその現物写真，図14はその 機構略図を示す。

\section{4 液状ゴム加工のまとめ}

以上が RAPRA方式による液状ゴム加工概略である が，次江全般的に見た液状コム加工の技術的急所を総括 的結論としてまとめよう.

\subsection{1 液状コムの特長}

1) 室温加硫の可能（熱エネルギー節約）

2）現場加硫の可能（スピードサービス）

3）投下资本設備が少なくてすむ

4）流動性による自動化, 省力化の可能

\subsection{2 加工技術の急所}

1）末端活性基維持一定のため，酸化防止安定都など 添加されているが，冷暗所眝蔵を必要とする. 使用 時には粘度，比重などで品兵管理する（固形ゴムと 違う)。

2）架橋剤についても同様, 安定化, 品所管理の必要 あり（特にイソシアナナート,ジアミン類の吸水 防止)

3）補強充てん剂： 粉末ゴム，液状ゴムを通じて生

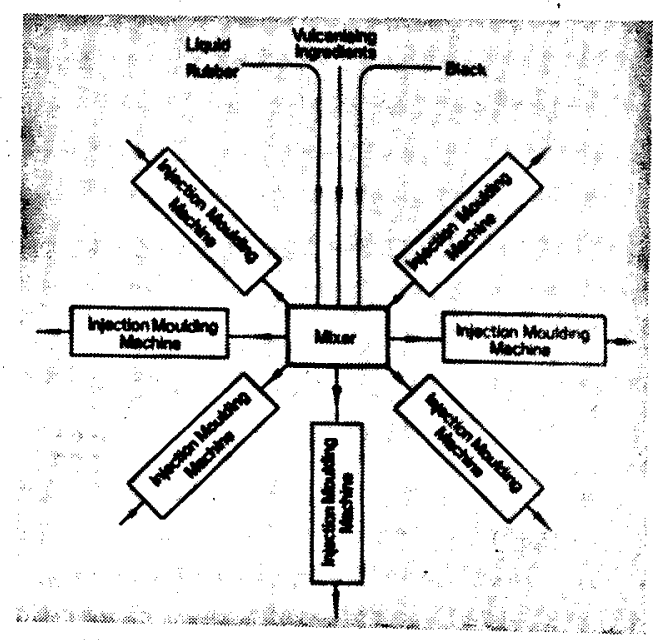

図11 液状ゴム用 7 連式射出成形加硫配置図

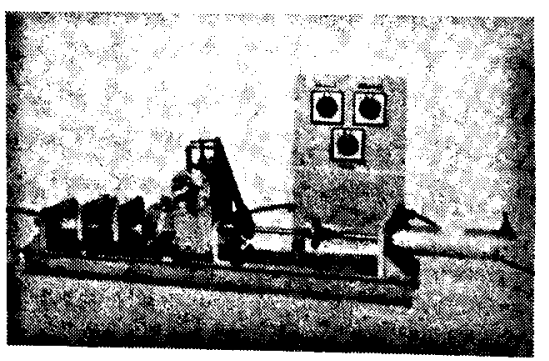

図12 液状ゴム射出成形機（実物写真） 


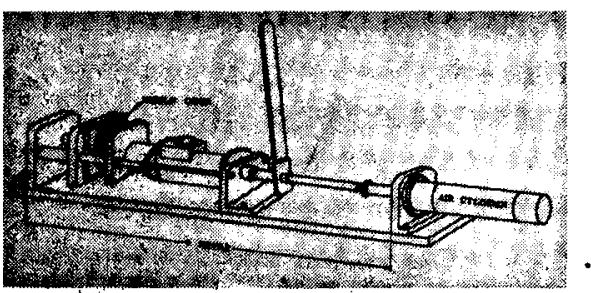

図13 液状ゴム射出成形機構図

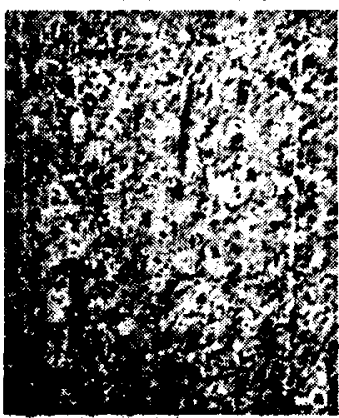

a RAPRA $\leqslant \neq+-$

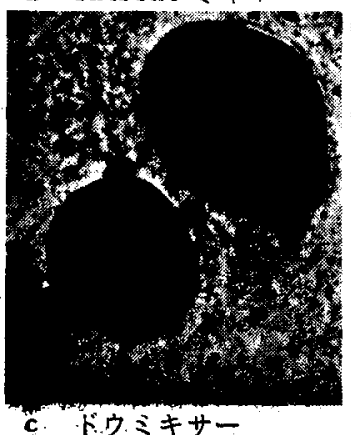

(加きませ機)

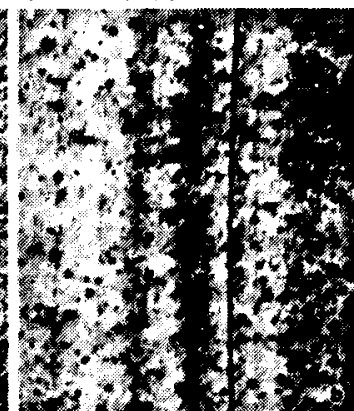

b 3 本ペイントロール

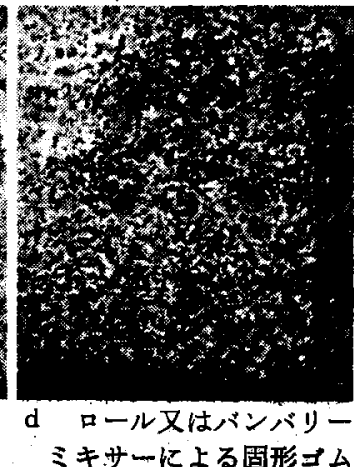

(参考比較)

图14 湤状ゴム・カーボンブラックの分散度

かする殺する補強放の使い方にある，従来の固形ゴ ムの素練りや混練時の有効なラジカル発生利用も利 加ず；また低粘度のため分散性も德い。したがって カーボンブラックでも最高級の弨徽㸮 SAF, ISAF を選定し，しかも構造性の低いL S 型を必要とす る. しかし現在主流を占める（我が国の場合）接着 版やシーラントの場合のような加硫ゴム物性を余り 必要としない場合は，MT ないし，FT カーボンで もまに合5. 含水性ホワイトカーボン (シリカ系) の堭合は均啠分散を助ける目的で低融点A C一ポリ エチレンやナフテン系プロをス油の少量添加を必要 とする.

4）混合方法：RAPRA の連続式に対し，次のよ5な バッチ式便法も可能である.むしろバッ千式が入門

技術としておもしろい。

\begin{tabular}{|c|c|c|c|}
\hline 混 合 法 & 便 & 法 & 正式 (RAPRA) \\
\hline 式 & パッ & & 連緭式 \\
\hline プレミキサー & 多理 & :-ダー & $\begin{array}{l}\text { 連立ラ公押出機 } \\
\text { と牄の併用 }\end{array}$ \\
\hline $\begin{array}{l}\text { インテンシフ } \\
\text { ミキサー }\end{array}$ & 三本 & ヘイントロ & $\begin{array}{l}\text { 強カタービン式 } \\
\text { キキーー }\end{array}$ \\
\hline ポーストミキサー & かき & & 混合押出機 \\
\hline
\end{tabular}

\section{5. 新形態ゴム加エの桔ひ}

㸮末ゴムにしろ，液状ゴムにしろあるいい将来生まれ るであろら気体ゴム（予言者ではないが私は信ずる）に しろ技街者として敏迎すべきであろら．それによって私 達の持てる技術分野は無限に拡大寸る. 技術的興味も深 まり研究意欲る増大し，ゴム工業万オである.

ただそれが決してなまやさしい「絵にかかれたもち」 や学者, 先生方が示される化学式どおりの理論どおりに はなかなかゆかないるのである. またポリマー原さんが いくら熱心に製造され，開発に努力されてもかんしんの 加工技街者が協力しなければむだ花に終わるおそれ無き にしもあらずである。，特にゴ工業の場合は，ポリマー 以外の配合薬品，補強剤はもちろん加工機械装貫メーカ 一の拹力，情牲的精神なしには完全を期しにくい，私が あえて初めに失敗的過去の歴史を紹介した理由である.

時代は，技術は，大きく転回しつつある. 黄ながら固 形ア゙ム追従懹古の時代は過ぎ去りつつある.71才の老む゙ ム费生すら痛感するくらいだから，若い鋭い新時代のコ ム技街者諸君は勇敢に取り組んでくれることを切望す る，理諭は不得手でも加工技術に関しては我々ゴム技街 者は誇り高い拾家荎を昔から持っている.

終わりに執筆に漈し刉用した文献を付記する. 順序不

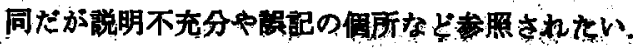

\section{考考嗝}

粉末古関保：

1) P. S. Byrne, H. F. Schwarz: Rubber Age, july, 43, (1973)

2) H. Widmer et al.: Rubber Age, nov. 41, (1974)

3) P. Woods et al.: Rubber World, Jul., 42, (1973)

4) H. Mannot et al.: RAPRA, Member Joụnal. 2, Oct. 1974 その他 RAPRA Abstract 液状ゴム関係：

R. T. Humpidge, S. H. Monrel: Proceeding of the International Conference (Brighton) 1972. E4-1. 